\title{
Growth and quality of Garcinia humilis seedlings as a function of substrate and shading level ${ }^{1}$
}

\author{
Bruna Luzia Barbosa da Silva², Edilson Costa ${ }^{2}$, \\ Flavio Ferreira da Silva Binotti ${ }^{2}$, Cleiton Gredson Sabin Benett ${ }^{3}$, Abimael Gomes da Silva ${ }^{4}$
}

\begin{abstract}
The successful establishment of a Garcinia humilis orchard depends on planting high-quality seedlings. This study aimed to evaluate the effects of the shading level $(0 \%$, $18 \%$ and $50 \%$ ) and substrate composition on the formation of $G$. humilis seedlings. Four substrates (S) were evaluated combining different proportions (v:v) of soil (SO), cattle manure $(\mathrm{CM})$, commercial substrate (CS), sand (SA) and fine grain vermiculite (FV): $\mathrm{S} 1=0 \% \mathrm{SO}+45 \% \mathrm{CM}+20 \% \mathrm{CS}+20 \%$ $\mathrm{SA}+15 \% \mathrm{FV} ; \mathrm{S} 2=15 \% \mathrm{SO}+30 \% \mathrm{CM}+20 \% \mathrm{CS}+20 \%$ $\mathrm{SA}+15 \% \mathrm{FV} ; \mathrm{S} 3=30 \% \mathrm{SO}+15 \% \mathrm{CM}+20 \% \mathrm{CS}+20 \%$ $\mathrm{SA}+15 \% \mathrm{FV} ; \mathrm{S} 4=45 \% \mathrm{SO}+0 \% \mathrm{CM}+20 \% \mathrm{CS}+20 \%$ $\mathrm{SA}+15 \% \mathrm{FV}$. The experiment was conducted in a completely randomized design in each environment, being the environments compared by a joint analysis. The G. humilis seedlings with the highest quality were obtained in the environment with a $50 \%$ shading screen. G. humilis seedlings do not grow when exposed to full sunlight and, therefore, the seedling production of this species with direct solar radiation, without some shading level, should not be recommended. Different combinations from the mixture of soil, cattle manure, commercial substrate, sand and fine grain vermiculite may be used in the formulation of substrates for $G$. humilis seedlings.
\end{abstract}

KEYWORDS: Garcinia humilis (Vahl) C. D. Adam; plant environment; cattle manure.

\section{INTRODUCTION}

Native to Bolivia, the Garcinia humilis (Vahl) C. D. Adam (Clusiaceae) fruit tree has been widely cultivated in Brazil, in recent years. This species produces a pleasant tasting fruit, with a white, juicy and sweet pulp that normally contains one large seed (Barbosa et al. 2008). G. humilis can be grown in different regions, since the soil and climatic conditions are suitable for plant growth and fruit

\section{RESUMO}

Qualidade e crescimento de mudas de achachairu em função do substrato e sombreamento

O sucesso no estabelecimento de um pomar de achachairu (Garcinia humilis) depende do plantio de mudas de alta qualidade. Objetivou-se avaliar os efeitos do nível de sombreamento (0\%, $18 \%$ e $50 \%$ ) e da composição do substrato na formação de mudas de achachairu. Foram avaliados quatro substratos (S) oriundos das combinações (v:v) de solo (SO), esterco bovino (EB), substrato comercial (SC), areia (AR) e vermiculita de granulometria superfina (VF), sendo: $\mathrm{S} 1=0 \% \mathrm{SO}+45 \% \mathrm{~EB}+20 \% \mathrm{SC}+20 \% \mathrm{AR}+$ $15 \% \mathrm{VF} ; \mathrm{S} 2=15 \% \mathrm{SO}+30 \% \mathrm{~EB}+20 \% \mathrm{SC}+20 \% \mathrm{AR}+$ $15 \% \mathrm{VF} ; \mathrm{S} 3=30 \% \mathrm{SO}+15 \% \mathrm{~EB}+20 \% \mathrm{SC}+20 \% \mathrm{AR}+$ $15 \% \mathrm{VF} ; \mathrm{S} 4=45 \% \mathrm{SO}+0 \% \mathrm{~EB}+20 \% \mathrm{SC}+20 \% \mathrm{AR}+15 \%$ VF. O experimento foi conduzido em delineamento inteiramente casualizado em cada ambiente, sendo os ambientes comparados por análise conjunta. As melhores mudas de achachairu foram produzidas no ambiente de tela com $50 \%$ de sombreamento. As mudas de achachairu não se desenvolveram a pleno sol e, portanto, não se recomenda a formação de mudas desta espécie com radiação direta, sem algum nível de sombreamento. Podem ser utilizadas diferentes composições oriundas da mistura de solo, esterco bovino, substrato comercial, areia e vermiculita superfina no substrato.

PALAVRAS-CHAVE: Garcinia humilis (Vahl) C. D. Adam; ambiência vegetal; esterco bovino.

production (Melo et al. 2017). This non-traditional fruit species has a great potential to be commercially exploited in the Brazilian tropical Savannah region and may be used in restoration and preservation programs of forest areas, as well as in the recovery of areas degraded due to damage from deforestation and tree burning, among others.

High-quality seedlings have a high survival rate in the field and are required for the implantation of commercial orchards and recovery of deforested

1. Received: Jun. 14, 2018. Accepted: Oct. 04, 2018. Published: Nov. 28, 2018. DOI: 10.1590/1983-40632018v4853500.

2. Universidade Estadual de Mato Grosso do Sul, Cassilândia, MS, Brasil.E-mail/ORCID: bruna_luziabarbosa@hotmail.com/ 0000-0001-7659-9601, mestrine@uems.br/0000-0002-4584-6611, binotti@uems.br/0000-0002-2248-8954.

3. Universidade Estadual de Goiás, Ipameri, GO, Brasil.E-mail/ORCID: cleiton.benett@gmail.com/0000-0001-7525-1857.

4. Universidade Estadual Paulista “Júlio de Mesquita Filho”, Ilha Solteira, SP, Brasil. E-mail/ORCID: ag.silva@unesp.br/ 0000-0001-7146-9226. 
areas. The production of quality seedlings requires the correct technical and sanitary management of the plants and the use of suitable substrates and protected environments. Screenhouses and greenhouses are examples of the seedling production environments that can provide micrometeorological conditions capable of improving the plant growth and quality (Darezzo et al. 2004, Costa et al. 2012). Thus, the light intensity and temperature within the seedling production environment may be limited (Paula et al. 2017), preventing abiotic stresses that may cause excessive evapotranspiration, photosynthetic capacity inhibition and impaired plant growth and development (Araújo \& Deminicis 2009, Taiz \& Zeiger 2013). The understanding of the types of production environment, covering material, color and shading level of the screen, among other factors, aims to identify the best environment that optimizes the growth potential of the plants.

In the production of $G$. humilis seedlings, Silva et al. (2018) compared two production environments with $50 \%$ shading screens and showed that the nursery with aluminized thermal-reflective screen resulted in more vigorous seedlings with a higher dry matter of shoots and roots, when compared to the nursery with black shading screen. Studies with sunlight restriction levels for forest tree species have reported that the $50 \%$ shading level resulted in high-quality seedlings for Schizolobium amazonicum Huber ex Ducke (Gondin et al. 2015), Caesalpinia ferrea C. Mart. (Lenhard et al. 2013), Copaifera langsdorffii Desf. (Dutra et al. 2012) and Physocalymma scaberrimum Pohl (Valadão et al. 2014).

The substrate is another factor that influences the emergence, growth and quality of forest and fruit tree seedlings. It should provide adequate physical, chemical and biological conditions for the seedling emergence and growth, such as a good aeration, water retention, nutrient availability and pathogen absence (Santos et al. 2011). The substrate may be obtained with the use of only one material or the combination of various materials; thus, it must be formulated to allow the development of the root system (Oliveira et al. 2012). Materials from organic or mineral sources are easy to acquire and have a good porosity to provide physicochemical properties essential to the requirements of each species. According to Silva et al. (2018), the use of substrate based on the mixture of cattle manure, soil, vermiculite and sand is adequate to produce $G$. humilis seedlings.
Thus, this study aimed to evaluate the effects of shading level and substrate composition on the formation of $G$. humilis seedlings, during the summer-fall period.

\section{MATERIAL AND METHODS}

The experiments with environments and substrates to produce G. humilis seedlings were conducted at the Universidade Estadual de Mato Grosso do Sul, in Cassilândia, Mato Grosso do Sul state, Brazil (19'07'21"S, 51 43 " 15 "W and $516 \mathrm{~m}$ of altitude), from November 2015 to May 2016.

$G$. humilis seeds were previously selected considering their size and then sown on November 7 (2015), in black polyethylene bags of $15.0 \mathrm{~cm} \times$ $25.0 \mathrm{~cm}(1.8 \mathrm{~L})$. The substrates $(\mathrm{S})$ were formulated from different proportions (v:v) of soil (SO), cattle manure $(\mathrm{CM})$, commercial substrate $(\mathrm{CS})$, sand (SA) and fine grain vermiculite (FV), as it follows: $\mathrm{S} 1=$ $0 \% \mathrm{SO}+45 \% \mathrm{CM}+20 \% \mathrm{CS}+20 \% \mathrm{SA}+15 \%$ $\mathrm{FV} ; \mathrm{S} 2=15 \% \mathrm{SO}+30 \% \mathrm{CM}+20 \% \mathrm{CS}+20 \%$ $\mathrm{SA}+15 \% \mathrm{FV} ; \mathrm{S} 3=30 \% \mathrm{SO}+15 \% \mathrm{CM}+20 \%$ $\mathrm{CS}+20 \% \mathrm{SA}+15 \% \mathrm{FV} ; \mathrm{S} 4=45 \% \mathrm{SO}+0 \% \mathrm{CM}+$ $20 \% \mathrm{CS}+20 \% \mathrm{SA}+15 \% \mathrm{~V}$. Two G. humilis seeds were sown per container, at a depth of $2.0 \mathrm{~cm}$, and, after the establishment, they were thinned to one plant per container.

Before using the fresh cattle manure, it was subjected to aerobic composting for 45 days. The composted material was then dried, homogenized and sifted through a 3.70-mm mesh. The soil was collected from the 0-30 cm depth layer of an Arenic Entisol (Embrapa 2013) with $110 \mathrm{~g} \mathrm{~kg}^{-1}$ of clay, $50 \mathrm{~g} \mathrm{~kg}^{-1}$ of silt and $840 \mathrm{~g} \mathrm{~kg}^{-1}$ of sand. The commercial substrate used was Bioplant Nature (Bioplant Agrícola Ltda., Nova Ponte, MG, Brazil), composed of coconut fiber, rice husk, pine bark and nutrients. The commercial substrate, vermiculite and sand were purchased from commercial companies. The soil and cattle manure were chemically characterized as shown in Table 1.

Seedlings were grown exposed to full sunlight and in two nurseries constructed with black shading screen $\left(\right.$ Sombrite ${ }^{\circledR}$ ) with $18 \%$ and $50 \%$ restriction of full daylight. The two protected environments used to produce G. humilis seedlings were: (i) agricultural shading screenhouse with a wood structure $(6.0 \mathrm{~m} \times$ $6.0 \mathrm{~m} \times 2.5 \mathrm{~m}$ ) and $18 \%$ shading screen on the sides and roof; (ii) agricultural shading screenhouse with a galvanized steel structure $(8.0 \mathrm{~m} \times 18.0 \mathrm{~m} \times 3.5 \mathrm{~m})$ 
Table 1. Chemical characteristics of the soil and cattle manure used in the composition of the substrates.

\begin{tabular}{lrc}
\hline \multicolumn{1}{c}{ Characteristic } & Soil & Cattle manure \\
\hline pH in water & 5.8 & 5.6 \\
Organic matter $\left(\mathrm{g} \mathrm{kg}^{-1}\right)$ & 20.6 & 200.0 \\
Carbon:nitrogen ratio & n.d. & $12: 1$ \\
Total nitrogen $\left(\mathrm{g} \mathrm{kg}^{-1}\right)$ & n.d. & 9.0 \\
Phosphorus $\left(\mathrm{mg} \mathrm{kg}^{-1}\right)$ & 1.8 & $1,310.0$ \\
Potassium $\left(\mathrm{mg} \mathrm{kg}^{-1}\right)$ & 165.0 & 833.0 \\
Calcium $\left(\mathrm{mg} \mathrm{kg}^{-1}\right)$ & 244.0 & $3,000.0$ \\
Magnesium $\left(\mathrm{mg} \mathrm{kg}^{-1}\right)$ & 53.5 & $1,000.0$ \\
Sulfur $\left(\mathrm{mg} \mathrm{kg}^{-1}\right)$ & 4.8 & 200.0 \\
Copper $\left(\mathrm{mg} \mathrm{kg}^{-1}\right)$ & 0.4 & 18.0 \\
Iron $\left(\mathrm{mg} \mathrm{kg}^{-1}\right)$ & 14.0 & $12,103.0$ \\
Manganese $\left(\mathrm{mg} \mathrm{kg}^{-1}\right)$ & 90.5 & 204.0 \\
Zinc $\left(\mathrm{mg} \mathrm{kg}^{-1}\right)$ & 1.7 & 53.0 \\
Sodium $\left(\mathrm{mg} \mathrm{kg}^{-1}\right)$ & 0.0 & 624.0 \\
\hline
\end{tabular}

n.d.: not determined.

and $50 \%$ shading screen on the sides and roof. The seedlings were watered daily and maintained in these environments for 201 days.

Since there were no replicates for the seedling production nurseries, each one was considered an individual experiment. In each production environment, the four substrate compositions were arranged in a completely randomized design, with five replicates of five seedlings each. The fact that the ratio between the mean square of the experimental error of the three individual experiments (i.e., seedling production environments) was less than 7.0 indicates that there was homogeneity between the residual mean square variances (Banzatto \& Kronka 2013); therefore, as the null hypothesis was accepted, the experiments were grouped to analyze the existence of interaction between substrates and production environments. Thus, the mean of the seedling production environments was compared by the joint analysis of data from the three experiments (Banzatto \& Kronka 2013).

At 201 days after sowing, the following characteristics were evaluated: plant height $(\mathrm{PH})$ measured $(\mathrm{cm})$ using a millimeter ruler; root collar diameter (CD) - determined ( $\mathrm{mm}$ ) using a digital caliper with accuracy of $\pm 0.01 \mathrm{~mm}$; shoot (SDM) and root (RDM) dry matter - the seedlings were separated into shoots and roots, dried in an oven at $65{ }^{\circ} \mathrm{C}$, for three days, and then weighed. From these measurements, the total dry matter (TDM) and Dickson quality index $\{\mathrm{DQI}=\mathrm{TDM} /[(\mathrm{PH} / \mathrm{CD})+$ (SDM/RDM)]\} were calculated (Dickson et al. 1960).
The data of air temperature $\left({ }^{\circ} \mathrm{C}\right)$ and relative humidity (\%) were gathered daily using a data logger (CDR-550, Instrutherm Instrumentos de Medição Ltda., São Paulo, SP, BRA) installed within the seedling nurseries. The photosynthetic photon flux density was measured daily at 10:00 a.m., with a photosynthetically active radiation meter (APGMQ-100, Apogee Instruments Ltda., Piracicaba, SP, BRA). Data collected during the experiments are shown in Table 2 and Figure 1. For the photosynthetic photon flux density, four replications and five data per plot were used.

The data were subjected to analysis of variance (F-test; $p=0.05$ ), and the means of the production environments and substrates were tested by the $\mathrm{F}$ and Tukey tests, respectively, both at the 0.05 level of confidence. All analyses were performed using the Sisvar software, version 5.6, for Windows.

\section{RESULTS AND DISCUSSION}

In the environment with exposure to full sunlight, there was only the emergence of six G. humilis seedlings and, therefore, this environment of seedling production was not used in the statistical analyzes of the measured morphological traits. This low emergence rate indicates that this fruit species requires shading and less light intensity for its adequate growth and development.

The shading levels directly influenced photosynthetically the active radiation inside the seedling nurseries, providing a lower light intensity with increased shading (Table 2). The mean temperature and relative humidity recorded in the production environments, during the experiment, were $25.7{ }^{\circ} \mathrm{C}$ and $72 \%$, respectively (Figure 1 ). These environmental conditions are similar to the values reported by Paula et al. (2017), who also found differences only for solar radiation data, when comparing protected and non-protected environments.

The high light intensity at the full sun environment was detrimental to the emergence and early growth of G. humilis seedlings (Table 2). Some plant species do not have adaptation mechanisms to environments with high direct solar radiation, and that may result in stresses due to photoinhibition (Araújo \& Deminicis 2009, Taiz \& Zeiger 2013), thus limiting plant growth (Lima et al. 2010). Similar results were observed for others forest and fruit tree 
Table 2. Average monthly values of photosynthetically active radiation $\left(\mu \mathrm{mol} \mathrm{m} \mathrm{m}^{-2} \mathrm{~s}^{-1}\right)$ at full sunlight and inside the seedling nurseries constructed with $18 \%$ and $50 \%$ shading screens, from November 2015 to May 2016.

\begin{tabular}{crrrrrrr}
\hline \multirow{2}{*}{ Sunlight restriction level } & \multicolumn{7}{c}{ Month/Year } \\
\cline { 2 - 7 } & Nov. 2015 & Dec. 2015 & Jan. 2016 & Feb. 2016 & Mar. 2016 & Apr. 2016 & May 2016 \\
\hline $50 \%$ & $484 \mathrm{~b} *$ & $553 \mathrm{~b}$ & $425 \mathrm{~b}$ & $564 \mathrm{c}$ & $503 \mathrm{~b}$ & $523 \mathrm{c}$ & $505 \mathrm{c}$ \\
$18 \%$ & $985 \mathrm{a}$ & $1,141 \mathrm{a}$ & $912 \mathrm{a}$ & $1,053 \mathrm{~b}$ & $998 \mathrm{ab}$ & $1,084 \mathrm{~b}$ & $912 \mathrm{~b}$ \\
$0 \%$ & $1,287 \mathrm{a}$ & $1,502 \mathrm{a}$ & $1,188 \mathrm{a}$ & $1,501 \mathrm{a}$ & $1,488 \mathrm{a}$ & $1,512 \mathrm{a}$ & $1,242 \mathrm{a}$ \\
\hline CV (\%) & 27.0 & 20.4 & 22.5 & 16.4 & 41.1 & 13.2 & 17.6 \\
\hline * Means followed by distinct uppercase letters in the columns show significant differences by the Tukey test at the 5\% probability level.
\end{tabular}

species, where the exposure of the seedlings to full sunlight was not favorable for seedling production, as reported for Schizolobium amazonicum (Gondin et al. 2015), Caesalpinia ferrea (Lenhard et al. 2013), Copaifera langsdorffii (Dutra et al. 2012) and Physocalymma scaberrimum (Valadão et al. 2014). These studies recommend production environments with shading screens for these plant species.

The results of the individual analysis showed that the ratio between the residual mean square of the
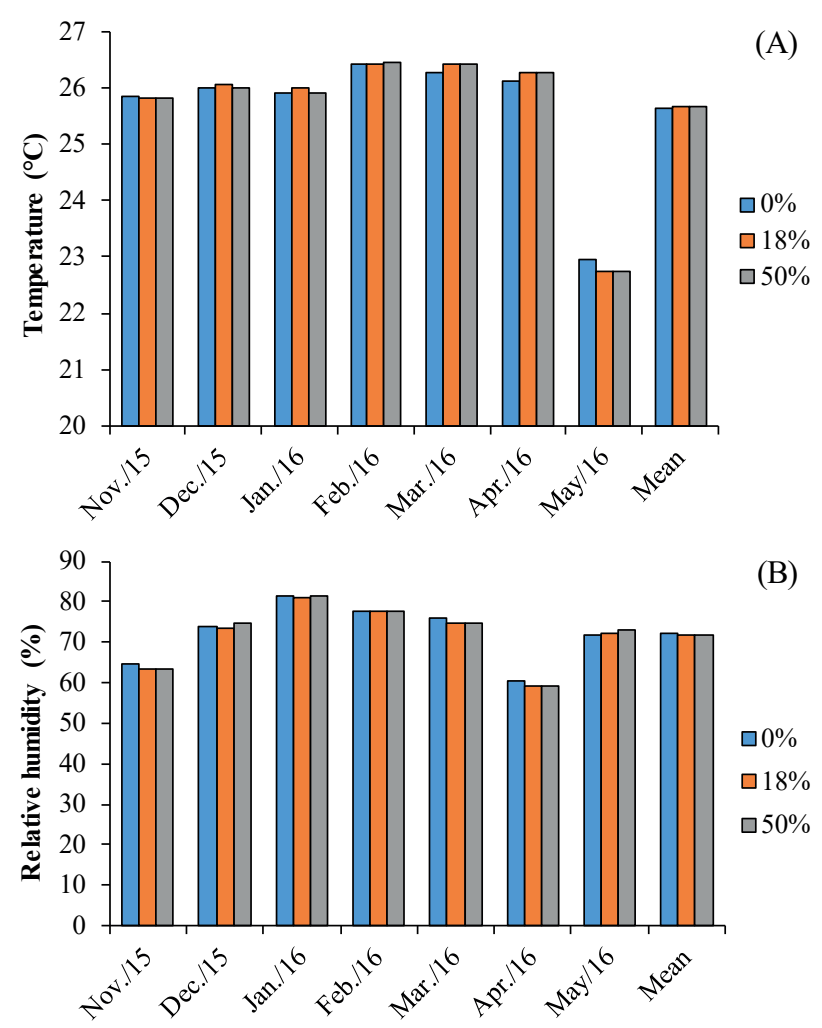

Figure 1. Average monthly values for air temperature (A) and relative humidity $(\mathrm{B})$ at full sunlight $(0 \%$ shading $)$ and inside the seedling nurseries constructed with $18 \%$ and $50 \%$ shading screens, from November 2015 to May 2016. two production environments was less than 7.0 for all traits measured. Therefore, as the residual mean square variances were homogeneous, the comparison of production environments was performed by the joint analysis of the two experiments (Banzatto \& Kronka 2013). The analysis of variance did not show significant effects $(p>0.05)$ for the interaction between substrates and production environments for any of the morphological traits. Therefore, the results are presented separately for the main effects of substrates and production environments (Table 3). The absence of significant interaction among the studied factors indicates that the different substrate combinations resulted in a similar growth response of the G. humilis seedlings at both light restriction levels.

The highest growth of the G. humilis seedlings was obtained in the environment with $50 \%$ restriction of full daylight (Table 3). In this environment, the seedlings presented a larger growth in height and root collar diameter, being, on average, $1.5 \mathrm{~cm}$ and $0.23 \mathrm{~mm}$ larger in height and root collar diameter, respectively, when compared to the environment with $18 \%$ of light restriction. Similar results were reported by Daniel (2009), who showed that the adequate growth of $G$. humilis plants occurs in an environment with at least $40 \%$ of shading. Other studies for forest and fruit tree species, at different light restriction levels, showed that $50 \%$ of shading resulted in a better plant growth. For example, for Schizolobium amazonicum seedlings, this level of light restriction was better than full sunlight conditions (Gondin et al. 2015); for Caesalpinia ferrea seedlings, it was better than $0 \%$ and $70 \%$ (Lenhard et al. 2013); for Copaifera langsdorffii seedlings, it was better than $0 \%, 30 \%$ and $70 \%$ (Dutra et al. 2012); and, for Physocalymma scaberrimum seedlings, it was better than $0 \%, 30 \%, 70 \%$ and $90 \%$ (Valadão et al. 2014).

Other plant species showed a higher seedling growth at full sunlight conditions, as reported by 
Table 3. Plant height (PH), root collar diameter (CD), shoot dry matter (SDM), root dry matter (RDM), total dry matter (TDM) and Dickson quality index (DQI) of Garcinia humilis seedlings grown using different substrates and subjected to light restriction levels.

\begin{tabular}{|c|c|c|c|c|c|c|}
\hline Treatments & $\mathrm{PH}$ & $\mathrm{CD}$ & SDM & RDM & TDM & \multirow{2}{*}{ DQI } \\
\hline Light restriction & $\mathrm{cm}$ & $\mathrm{mm}$ & \multicolumn{3}{|c|}{ g plant ${ }^{-1}$} & \\
\hline $50 \%$ & $11.97 \mathrm{a}^{*}$ & $2.74 \mathrm{a}$ & $0.92 \mathrm{a}$ & $0.62 \mathrm{a}$ & $1.54 \mathrm{a}$ & $0.26 \mathrm{a}$ \\
\hline $18 \%$ & $10.47 \mathrm{~b}$ & $2.51 \mathrm{~b}$ & $0.54 \mathrm{~b}$ & $0.58 \mathrm{a}$ & $1.12 \mathrm{~b}$ & $0.22 \mathrm{~b}$ \\
\hline \multicolumn{7}{|l|}{ Substrates $^{\dagger}$} \\
\hline $\mathrm{S} 1$ & $11.00 \mathrm{a}$ & $2.61 \mathrm{a}$ & $0.71 \mathrm{a}$ & $0.59 \mathrm{a}$ & $1.30 \mathrm{a}$ & $0.24 \mathrm{a}$ \\
\hline $\mathrm{S} 2$ & $11.28 \mathrm{a}$ & $2.64 \mathrm{a}$ & $0.69 \mathrm{a}$ & $0.62 \mathrm{a}$ & $1.31 \mathrm{a}$ & $0.24 \mathrm{a}$ \\
\hline $\mathrm{S} 3$ & $11.65 \mathrm{a}$ & $2.73 \mathrm{a}$ & $0.81 \mathrm{a}$ & $0.64 \mathrm{a}$ & $1.45 \mathrm{a}$ & $0.26 \mathrm{a}$ \\
\hline $\mathrm{S} 4$ & $10.96 \mathrm{a}$ & $2.51 \mathrm{a}$ & $0.70 \mathrm{a}$ & $0.56 \mathrm{a}$ & $1.27 \mathrm{a}$ & $0.23 \mathrm{a}$ \\
\hline $\mathrm{CV}(\%)$ & 12.28 & 7.35 & 33.87 & 17.73 & 25.38 & 22.61 \\
\hline
\end{tabular}

* Means followed by distinct letters for the factors light restriction level and substrates show significant differences by the $\mathrm{F}$ and Tukey tests, respectively, both at the $5 \%$ probability level. ${ }^{\dagger} \mathrm{S} 1: 0 \%$ soil $+45 \%$ cattle manure $+20 \%$ commercial substrate $+20 \%$ sand $+15 \%$ vermiculite; S $2: 15 \%$ soil $+30 \%$ cattle manure $+20 \%$ commercial substrate $+20 \%$ sand $+15 \%$ vermiculite; S3: $30 \%$ soil $+15 \%$ cattle manure $+20 \%$ commercial substrate $+20 \%$ sand $+15 \%$ vermiculite; S4: $45 \%$ soil $+0 \%$ cattle manure $+20 \%$ commercial substrate $+20 \%$ sand $+15 \%$ vermiculite.

Araújo et al. (2006) for Carica papaya L. seedlings, showing that the plants exposed to full sunlight had a higher number of leaves and a larger root collar diameter, when compared to those produced under $50 \%$ of light restriction. Scalon et al. (2001) also reported a higher adaptation of Eugenia uniflora L. seedlings to full sunlight conditions (no shading), and the seedlings produced in light restricted environments showed a lower dry matter yield.

The production of shoot and total dry matter were higher in the seedlings under $50 \%$ of light restriction (Table 3), confirming that the $50 \%$ shading environment is appropriate for the growth of $G$. humilis plants. However, the root dry matter was not influenced by the cultivation of seedlings in a shaded environment. The dry matter accumulation in the plants is related to the net photosynthesis rate of the plant, which is affected by the respiration and photorespiration rates (in plants with metabolism $\mathrm{C}_{3}$ ), influenced by the morphophysiological adaptations of the plant (Taiz \& Zeiger 2013). In $\mathrm{C}_{3}$ metabolism plants, such as G. humilis, the photorespiration may reach high rates under conditions of high light intensity and temperature, what leads to losses in the incorporation of $\mathrm{CO}_{2}$, resulting in a lower dry matter accumulation.

The different substrates did not significantly affect the plant growth and dry matter accumulation of the G. humilis seedlings (Table 3). These results suggest that the nutritional requirements of this species were fully satisfied during the growth period, regardless of the proportion of cattle manure or soil in the substrate. G. humilis had a different response to that of other fruit species, considering the amount of cattle manure contained in the substrate as a source of organic matter and nutrients. Dipteryx alata Vog. seedlings, for example, have a lower dry matter yield in substrates with a higher proportion of cattle manure (Costa et al. 2015), the same happening for Hancornia speciosa seedlings (Dias et al. 2009).

The environment with $50 \%$ restriction of full daylight provided the Dickson quality index, when compared to the $18 \%$ shading level (Table 3 ). This improvement in the seedling growth with less availability of photosynthetically active radiation of the environment with $50 \%$ of shading (Table 2) indicates that the light intensity was not limiting for the growth of the plants. Contrary results were reported by Salles et al. (2017), which showed that the adaptive response of Syzygium cumini (L.) Skeels seedlings to an environment with $18 \%$ of light restriction was higher than the $50 \%$ shading level. The results presented here show that $G$. humilis had a better adaptation to the environment with $50 \%$ of shading. Factors such as light intensity, temperature and relative air humidity may directly affect the photosynthesis rate of the plants. In this study, it was evident that the high availability of active photosynthetic radiation (Table 2) did not contribute to the growth of G. humilis seedlings (Table 3). The lower radiation availability in the environment does not always result in a positive response in the plant growth under shaded conditions, because the active photosynthetic radiation may limit the photosynthesis rate and plant growth, reflecting in a lower seedling quality. However, high levels of photosynthetically 
active radiation may also cause a decrease in the photosynthetic rate, due to abiotic stress, causing a high transpiration rate and photoinhibition.

The interaction of this species with the environment with a greater shading level was shown to be the most adequate for the cultivation of the seedlings, because the plant growth in height and root collar diameter resulted in a greater accumulation of shoot and total dry matter. This fact indicates that there was an adequate allocation of dry matter to the different plant organs, in order to capture the light energy and provide an adequate growth of the seedlings, resulting in a greater resistance of them to the adverse conditions of the environment.

It is important to point out that growth variables should not be considered in isolation for choosing the best quality seedlings. Thus, the choice of quality seedlings using the Dickson quality index is more reliable, considering several variables in a single biometric index that demonstrates the equilibrium of the dry biomass distribution, and allows to determine the most rustic seedlings (Fonseca et al. 2002, Marana et al. 2015).

\section{CONCLUSIONS}

1. The Garcinia humilis seedlings with higher quality are obtained in an environment with a $50 \%$ shading screen;

2. G. humilis seedlings do not grow when exposed to full sunlight, during the summer-fall period, and, therefore, the seedling production of this species with direct solar radiation, without some shading level, should not be recommended;

3. Different combinations of soil, cattle manure, commercial substrate, sand and vermiculite may be used in the formulation of substrates to produce high-quality G. humilis seedlings.

\section{REFERENCES}

ARAÚJO, J. R. G. et al. Efeito do recipiente e ambiente de cultivo sobre o desenvolvimento de mudas de mamoeiro cv. Sunrise Solo. Revista Brasileira de Fruticultura, v. 28, n. 3, p. 526-529, 2006.

ARAÚJO, S. A. C.; DEMINICIS, B. B. Fotoinibição da fotossíntese. Revista Brasileira de Biociências, v. 7, n. 4, p. 463-472, 2009.

BANZATTO, D. A.; KRONKA, S. N. Experimentação agrícola. 4. ed. Jaboticabal: Funep, 2013.
BARBOSA, W. et al. Germinação de sementes e desenvolvimento inicial de plântulas de achachairu. Revista Brasileira de Fruticultura, v. 30, n. 1, p. 263266, 2008.

COSTA, E. et al. Diferentes composições de substratos e ambientes protegidos na formação de mudas de pé-franco de tamarindeiro. Revista Brasileira de Fruticultura, v. 34, n. 4, p. 1189-1198, 2012.

COSTA, E. et al. Telas de sombreamento e substratos na produção de mudas de Dipteryx alata Vog. Floresta e Ambiente, v. 22, n. 3, p. 416-425, 2015.

DANIEL, A. B. El Cultivo del achachairú (Garcinia humilis): manual de recomendaciones. Santa Cruz: CIAT, 2009.

DAREZZO, R. J. et al. Cultivo em ambiente protegido: histórico, tecnologia e perspectiva. In: AGUILERA, R. L. et al. (Eds.). Cultivo em ambiente protegido: histórico, tecnologia e perspectiva. Viçosa: UFV, 2004. p. 1-8.

DIAS, T. J. et al. Desenvolvimento e qualidade nutricional de mudas de mangabeiras cultivadas em substratos contendo fibra de coco e adubação fosfatada. Revista Brasileira de Fruticultura, v. 31, n. 2, p. 512-523, 2009.

DICKSON, A. et al. Quality appraisal of white spruce and white pine seedling stock in nurseries. Forestry Chronicle, v. 36, n. 1 , p. $10-13,1960$.

DUTRA, T. R. et al. Desenvolvimento inicial de mudas de copaíba sob diferentes níveis de sombreamento e substratos. Revista Ciência Agronômica, v. 43, n. 2, p. 321-329, 2012.

EMPRESA BRASILEIRA DE PESQUISA AGROPECUÁRIA (Embrapa). Sistema brasileiro de classificação de solos. 3. ed. Brasília, DF: Embrapa, 2013.

FONSECA, E. P. et al. Padrão de qualidade de mudas de Trema micrantha (L.) Blume, produzidas sob diferentes períodos de sombreamento. Revista Árvore, v. 26, n. 4, p. 515-523, 2002.

GONDIN,J.C. etal.EmergênciadeplântulasdeSchizolobium amazonicum Huber ex Ducke (Caesalpinaceae) em diferentes substratos e sombreamentos. Revista Ciência Agronômica, v. 46, n. 2, p. 329-338, 2015.

LENHARD, N. R. et al. Crescimento de mudas de pauferro sob diferentes níveis de sombreamento. Pesquisa Agropecuária Tropical, v. 43, n. 2, p. 178-186, 2013.

LIMA, A. L. S.; ZANELLA, F.; CASTRO, L. D. M. Crescimento de Hymenaea courbaril L. var. stilbocarpa (Hayne) Lee et Lang. e Enterolobium contortisiliquum (Vell.) Morong (Leguminosae) sob diferentes níveis de sombreamento. Acta Amazonica, v. 40, n. 1, p. 43-48, 2010. 
MARANA, J. P.; MIGLIORANZA, E.; FONSECA, E. P. Qualidade de mudas de jaracatiá submetidas a diferentes períodos de sombreamento em viveiro. Revista Árvore, v. 39, n. 2, p. 275-282, 2015.

MELO, M. S. et al. Análise físico-química de frutos de achachairu coletados em diferentes partes da planta. Revista de Agricultura Neotropical, v. 4, supl., p. 17-21, 2017.

OLIVEIRA, K. S.; OLIVEIRA, K. S.; ALOUFA, M. A. I. Influência de substratos na germinação de sementes de Anadenanthera colubrina (Vell.) Brenan em condições de casa de vegetação. Revista Árvore, v. 36, n. 6, p. 10731078, 2012.

PAULA, R. C. M. et al. Monitoramento de variáveis micrometeorológicas em diferentes ambientes protegidos no período de inverno. Revista de Agricultura Neotropical, v. 4, supl., p. 103-109, 2017.

SALLES, J. S.; LIMA, A. H. F.; COSTA, E. Mudas de jambolão sob níveis de sombreamento, bancadas refletoras e profundidade de semeadura. Revista de Agricultura Neotropical, v. 4, supl., p. 110-118, 2017.

SANTOS, L. C. R. et al. Ambientes protegidos e substratos com doses de composto orgânico comercial e solo na formação de mudas de jatobazeiro em Aquidauana - MS. Engenharia Agrícola, v. 31, n. 2, p. 249-259, 2011.

SCALON, S. P. Q.; SCALON FILHO, H.; VERALDO, F. Germinação e crescimento de mudas de pitangueira (Eugenia uniflora L.) sob condições de sombreamento. Revista Brasileira de Fruticultura, v. 23, n. 3, p. 652-655, 2001.

SILVA, B. L. B. et al. Protected environments and substrates for achachairu seedlings. Engenharia Agrícola, v. 38, n. 3, p. 309-318, 2018.

TAIZ, L.; ZEIGER, E. Fisiologia vegetal. 3. ed. Porto Alegre: Artmed, 2013.

VALADÃO, M. B. X. et al. Initial development and biomass partitioning of Physocalymma scaberrimum Pohl (Lythraceae) under different shading levels. Scientia Forestalis, v. 42, n. 101, p. 129-139, 2014. 